\title{
HUBUNGAN BILATERAL PEMERINTAH REPUBLIK INDONESIA DAN PEMERINTAH AUSTRALIA DALAM BIDANG EKONOMI KREATIF
}

\author{
Adi Joko Purwanto ${ }^{1}$ dan Isma Wati ${ }^{2}$ \\ ${ }^{1}$ Dosen Hubungan Internasional, Fisip Unwahas dan ${ }^{2}$ Mahasiswa tingkat akhir \\ Hubungan Internasional, Fisip Unwahas \\ Email: ajpfisipolhiuwh@gmail.com
}

\begin{abstract}
The process of globalization of a country with other countries aimed at meeting the needs of the people and for the interests of countries in the world. Cooperation relations between countries are needed for the necessities of life and the existence of a state in international social relations, in addition to the creation of peace and prosperity which is the dream of every human being and the country in the world. Each country has different advantages, disadvantages and interests. These are the things that encourage international relations and cooperation. The author uses constructivism theory that goes into the study of international relations which emphasizes the importance of ideas, identity, in determining interests. Then the world order will understand the constructivist view of the bilateral relations between Indonesia and Australia in the creative economy.
\end{abstract}

Keywords: bilateral, Indonesia, Australia, creative economy.

\section{A. Pendahuluan}

Proses globalization suatu negara dengan negara lain yang bertujuan untuk memenuhi kebutuhan rakyat dan untuk kepentingan negara-negara di dunia. Banyak hal dilakukukan oleh negara maju atau berkembang dalam kerjasama internasional, yang meliputi kerja sama di bidang politik, sosial, pertahanan keamanan, kebudayaan, dan ekonomi, berpedoman pada politik luar negeri masing-masing. Berdasarkan bentuknya, kerja sama ekonomi internasional terbagi dalam 4 (empat) macam, kerjasama bilateral, kerjasama regional, kerjasama multilateral, kerjasama internasional.

Hubungan kerjasama antar negara (internasional) di dunia diperlukan guna memenuhi kebutuhan hidup dan eksistensi keberadaan suatu negara dalam tata pergaulan internasional, di samping demi terciptanya perdamaian dan kesejahteraan hidup yang merupakan dambaan setiap manusia dan negara di 
dunia. Setiap negara sudah tentu memiliki kelebihan, kekurangan dan kepentingan yang berbeda. Hal-hal inilah yang mendorong dilakukannya hubungan dan kerjasama internasional. Pada dasarnya hubungan internasional dititikberatkan pada bidang pertahanan dan keamanan, ekonomi, sosial budaya, dan bahkan ideologi. Umumnya bidang - bidang tersebutlah yang melatarbelakangi terjadinya hubungan internasional.

Memelihara dan menciptakan hidup secara damai dan adil dengan bangsa lain dengan mencegah dan menyelesaikan konflik, perselisihan, permusuhan, atau persengketaan yang mengancam perdamaian dunia sebagai akibat adanya kepentingan nasional yang berbeda di antara bangsa dan negara di dunia. Bekerjasama mengembangkan cara penyelesaian masalah secara damai melalui perundingan dan diplomasi yang ditempuh negara - negara, cinta damai, dan berpegang kepada nilai - nilai etik dalam pergaulan antarbangsa. Banyak negara pun membangun solidaritas dan sikap saling menghormati antarbangsa dengan membantu bangsa lain yang terancam keberadaannya sebagai akibat pelanggaran atas hak - hak kemerdekaan yang dimiliki. Semua negara pasti memiliki mimpi yang sama untuk berpastisipasi dalam rangka ikut melaksanakan ketertiban dunia berdasarkan kemerdekaan, perdamaian abadi, dan keadilan sosial serta menjamin kelangsungan hidup bangsa dan negara, kelangsungan keberadaan dan kehadirannya di tengah bangsa - bangsa lain. Namun terkadang memiliki cara dan motif kerjasama yang berbeda karena setiap negara mempunyai national interest dan foreign policy masing-masing.

Kerjasama ekonomi internasional dipengaruhi oleh Globalisasi ekonomi, Adanya keinginan melakukan kerja sama dengan negara lain dan berbagai faktor seperti Sumber daya alam, keadaan ekonomi, aktor produksi, iklim, ideologi yang berbeda dan perbedaan ilmu pengetahuan dan teknologi yang dikuasai dan melakukan penghematan biaya produksi. Sebuah negara dapat melakukan hubungan internasional setelah mendapat pengakuan secara 'de facto' maupun 'de jure' oleh negara - negara lainnya. Perlunya kerja sama internasional dipengaruhi oleh dua faktor, diantaranya sebagai berikut. 
a. Faktor internal adalah adanya kekhawatiran, terancam kelangsungan hidupnya baik melalui kudeta maupun intervensi dari negara lain.

b. Faktor eksternal adalah ketentuan hukum alam yang tidak dapat dipungkiri bahwa suatu negara tidak dapat berdiri sendiri tanpa bantuan dan kerja sama dengan negara lain. Ketergantungan tersebut terutama dalam upaya memecahkah masalah - masalah ekonomi, politik, hukum dan sebagainya.

Kerjasama internasional berharap negara-negara saling menghargai dan menghormati ideology masing-masing, saling menguntungkan kedua belah pihak dalam meningkatkan kesejahteraan ekonomi, meningkatkan penerapan iptek serta menanggulangi hal-hal yang dapat merusakbudaya, meningkatkan kemampuan pertahanan dan keamanan, mewujudkan ketertiban dan perdamaian dunia. Terlebih dengan negara-negara yang secara geografis berdekatan, diharap mampu menjaga keharmonisan dan kerjasama antar negara. Indonesia dan Australia misalnya, negara bertetangga yang telah terwujud dalam program bilateral.

Hubungan antara Indonesia dan Australia memiliki sejarah yang cukup panjang sejak zaman perjuangan kemerdekaan Indonesia. Australia merupakan salah satu dari sejumlah negara di dunia yang pertama mengakui hak Indonesia untuk merdeka. Dalam perkembangannya, hubungan bilateral antara Indonesia dan Australia mengalami pasang surut. Hal tersebut terjadi karena berbagai perbedaan yang ada di antara kedua negara, antara lain, perbedaan yang terkait dengan sistem politik, kondisi sosial, ekonomi, dan kebudayaan. Namun, fakta geografis yang menunjukkan bahwa kedua negara merupakan negara bertetangga menjadi faktor yang mendorong perlunya kedua negara untuk berinteraksi secara kondusif guna menjaga stabilitas kawasan.

Pada era globalisasi dan konektivitas mengubah cara bertukar informasi, berdagang, dan konsumsi dari produk-produk budaya dan teknologi dari berbagai tempat di dunia. Dunia menjadi tempat yang sangat dinamis dan kompleks sehingga kreativitas dan pengetahuan menjadi suatu aset yang tak ternilai dalam kompetisi dan pengembangan ekonomi. Hubungan Bilateral Ekonomi Kreatif antara Indonesia dan Singapura adalah sebuah konsep yang menempatkan 
kreativitas dan pengetahuan sebagai aset utama dalam menggerakkan ekonomi. Konsep ini telah memicu ketertarikan melakukan kajian seputar Ekonomi Kreatif dan menjadikan Ekonomi Kreatif model utama pengembangan ekonomi.

Dimulai dari 31 Agustus 2018 Pemerintah Republik Indonesia dan Pemerintah Australia menjalin kerjasama ekonomi kreatif. Memorandum of Understanding ditantatangani oleh Kepala Badan Ekonomi Kreatif (Bekraf), Triawan Munaf dan Minister for Communications and the Arts, Senator the Hon, Mitch Fifield.

\section{A. Rumusan Masalah}

Mengapa Pemerintah Republik Indonesia menjalin kerjasama bilateral dengan Pemerintah Australia dalam bidang ekonomi kreatif?

B. Teori

Dalam penelitian ini penulis menggunakan pandangan yaitu teori kontruktivisme. Teori konstruktivisme yang masuk ke dalam studi hubungan internasional dengan tokoh Alexander Wend, Onuf. Mereka menekankan pentingnya ide, identitas, dalam menentukan kepentingan. ${ }^{1}$ Konstruktivisme sebenarnya bukan merupakan gagasan yang baru, apa yang dilalui dalam kehidupan kita selama ini merupakan himpunan dan pembinaan pengalaman demi pengalaman. Ini menyebabkan seseorang mempunyai pengetahuan dan menjadi lebih dinamis. Piaget yang dikenal sebagai konstruktivis pertama (Dahar, 1989: 159) menegaskan bahwa penekanan teori kontruktivisme pada proses untuk menemukan teori atau pengetahuan yang dibangun dari realitas lapangan.

Dengan metodologi mempertanyakan secara kritis dari mana datangnya identitas dan kepentingan tersebut. Identitas dan kepentingan bukan realitas melainkan bentukan struktur dan teori. Menekankan pentingnya kekuatan Ide-ide yang ada. Menjadikan kekuatan ide sangat berperan penting dalam kehidupan sosial dalam menentukan pilihan di antara perimbangan keberagaman sosial.

\footnotetext{
${ }^{1}$ Abubakar Eby Hara, Pengantar Analisis Politik Luar Negeri: Dari Realisme sampai Konstruktivisme (Bandung: Nuansa, 2011).
} 
Institusi merupakan struktur sosial yang berfungsi untuk "sharing gagasan". Kepentingan dan identitas negara selalu dikonstruksikan dalam sistem HI. ${ }^{2}$

\section{Pembahasan}

Pemerintah Indonesia dan Australia sedang memulai proses Memorandum of Understanding mengenai ekonomi kreatif untuk memfasilitasi kerja sama yang lebih baik di sektor yang sedang tumbuh ini. Kedua negara ini berhasrat memperkuat hubungan persahabatan yang telah dibangun antara kedua negara di segala bidang. Terlebih dengan keadaan geografis yang berdekatan menjadikan kerjasama bilateral kedua negara semakin banyak. Walaupun terkadang menemukan masalah-masalah yang menghambat hubungan bilateral, namun dengan adanya negosiasi oleh kedua perwakilan resmi negara hubungan semakin membaik.Dengan berkomitmen bersama untuk meningkatkan sesuai dengan kemampuan kedua negara melalui promosi kerjasama di bidang yang telah disepakati berdasarkan prinsip kesetaraan, saling menghormati dan menguntungkan.

Hubungan antara Indonesia dan Australia memiliki sejarah yang cukup panjang sejak zaman perjuangan kemerdekaan Indonesia. Australia merupakan salah satu dari sejumlah negara di dunia yang pertama mengakui hak Indonesia untuk merdeka. Pada 31 Agustus 2018, Pemerintah RI dan Australia telah mengakui bersama dalam kemitraan komperehensif antara Australia dan RI dalam bidang ekonomi kreatif guna melanjutkan kerjasama Budaya antara Pemerintah Persemakmuran Australia dan Pemerintah RI ditandatangani pada 14 Juni 1968. Memorandum of Understanding ditantatangani oleh Kepala Badan Ekonomi Kreatif (Bekraf), Triawan Munaf dan Minister for Communications and the Arts, Senator the Hon, Mitch Fifield. Peran peningkatan prioritas dari ekonomi kreatif di dalam pengembangan ekonomi kedua negara, dan memandangnya sebagai instrumen positif untuk peningkatan kualitas hidup seluruh rakyat.

2 Wendt ,Alexander E.1987. The Agent-Structure Problem in International Relations Theory. International Organization, Vol. 41, No. 3. (Summer, 1987), pp. 335-370. 
Berdasarkan hukum dan peraturan perundang-undangan yang berlaku di kedua negara mempunyai tujuan baik, untuk mempromosikan kerjasama dan saling pengertian antara rakyat dari kedua negara di bidang ekonomi kreatif yang dapat memberikan kepentingan dan keuntungan bersama. Kedua pemerintah akan berusaha untuk bekerja sama dalam mengidentifikasi langkah-langkah yang tepat untuk mendorong pertukaran informasi, keahlian profesional dan kegiatan ekonomi kreatif.

Kerjasama yang dilakukan kedua pemerintah meliputi :

a. Penyiaran

b. Seni Visual, termasuk kerajinan, Seni Rupa dan Fotografi;

c. Industri Kreatif, termasuk Seni Pertunjukan, Produksi Layar termasuk Animasi, dan efek visual, Game, musik, sastra dan penerbitan, arsitektur, design dan fashion.

d. Warisan budaya

e. Bidang kerjasama lainnya yang ditentukan bersama secara tertulis oleh para pihak. $^{3}$

Melihat dari pandangan teori contructivisme Pemerintah Australia dan Pemerintah Republik Indonesia saling bergantung disebabkan oleh kerjasama kedua negara dimulai dari Indonesia merdeka. Dengan waktu yang tidak sedikit memungkinkan untuk selalu bekerja sama karena potensi dan keragaman yang dimiliki kedua negara cenderung berbeda. Konstruktivisme berusaha menunjukkan bahwa aspek-aspek inti hubungan internasional dikonstruksi secara sosial, artinya aspek tersebut diwujudkan oleh proses praktik dan interaksi sosial. Kedua negara telah memperlihatkan wujud proses praktik dan interaksi sosial yang dilakukan pemerintah, organisasi internasional atau warga negara.

Alexander Wendt menyatakan bahwa dua inti dasar konstruktivisme adalah "struktur hubungan manusia lebih ditentukan oleh gagasan bersama alih-alih

\footnotetext{
${ }^{3}$ Nota Kesepahaman tentang Kerjasama di Bidang Ekonomi Kreatif antara Pemerintah Republik Indonesia dan Pemerintah Australia.Treaty database.kemlu.go.id
} 
dorongan materi, dan identitas beserta kepentingan aktor yang berkepentingan dikonstruksi oleh gagasan bersama alih-alih diturunkan secara alamiah. MoU yang telah disepakati bersama merupakan gagasan bersama berawal karena kesenjangan komunikasi. Berbeda ideologi dan keanekaragaman kedua negara menjadikan alasan untuk membuat kolaborasi.

Memberi ruang bagi identitas dan kepentingan aktor internasional dalam teori hubungan internasional. Karena para aktor tidak dikendalikan oleh sistem mandiri, identitas dan kepentingannya perlu dilibatkan dalam analisis perilaknya. Seperti sifat sistem internasional, para konstruktivis memandang bahwa identitas dan kepentingan tidak didasarkan secara objektif pada desakan material (misalnya sifat manusia yang mendasari realisme klasik), namun merupakan hasil dari gagasan dan konstruksi sosial terhadap gagasan tersebut. Dengan kata lain, makna gagasan, objek, dan aktor dibentuk oleh interaksi sosial. Manusia memberi makna terhadap objek tersebut dan memberi banyak sekali makna terhadap berbagai hal. Dalam MoU yang dilakukan kedua pemerintah melibatkan pihak ketiga, seperti organisasi atau lembaga industri kreatif terkait dan sektor swasta dalam bentuk partisipasi dalam kemitraan. Misalnya kerjasama dari instansi akademik, University of Technology Sydney dan Institut Teknologi Bandung, 4 menandatangani nota kesepahaman untuk bekerja sama dalam mendorong lebih banyak perusahaan-perusahaan start-up di Indonesia, mempromosikan kehidupan perkotaan yang berkelanjutan, kesehatan dan kesejahteraan, serta melibatkan warga. Dampak baik muncul dari hubungan bilateral kedua negara melewati pihak ketiga. Dengan begitu kedua warga negara semakin sadar akan kehidupan sosial yang tidak dapat melangkahi takdir yakni bergantung pada lingkungan sekitar.

Konstruktivis dianggap lebih optimis dengan kemajuan hubungan internasional. Konstruktivis memberikan perhatiannya pada kepentingan dan identitas negara sebagai produk yang dapat dibentuk dari proses sejarah yang

\footnotetext{
${ }^{4}$ Embassy Australia. Indonesia dan Australia: Mitra untuk Era Digital https://indonesia.embassy.gov.au/jaktindonesian/SM18_007.html
} 
khusus. Mereka memberi perhatian pada wacana umum yang ada ditengah masyarakat karena wacana merefleksikan dan membentuk keyakinan dan kepentingan, dan mempertahankan norma-norma yang menjadi landasan bertindak masyarakat (accepted norms of behavior). Dengan demikian konstruktivis memberi perhatian pada sumber-sumber perubahan (sources of change). Dengan optimisme yang tinggi, kedua negara berharap kerjasama dalam bidang ekonomi kreatif dalam berjalan secara terus menerus. Dari MoU yang ditantatangipun tertera kerjasama akan berakhir jika salah satu pihak memutuskan kerjasama nya dengan syarat memberi alasan tertulis sejak 6 bulan sebelum kerjasama dihentikan. Bermakna optimisme tinggi yang dipercaya kedua negara dalam melakukan kerjasama ini.

\section{PENUTUP}

\section{Kesimpulan}

Memelihara dan menciptakan hidup secara damai dan adil dengan bangsa lain dengan mencegah dan menyelesaikan konflik, perselisihan, permusuhan, atau persengketaan yang mengancam perdamaian dunia sebagai akibat adanya kepentingan nasional yang berbeda di antara bangsa dan negara di dunia. Namun dengan menyatukan gagasan atau ide setiap kepentingan negara menjadikan dunia semakin damai. Melalui teori kontruktifime penulis berharap pembaca mampu memahami perkembangan hubungan bilateral Pemerintah Republik Indonesia da Pemerintah Australia yang semakin membaik. Program bersama kedua negara yakni Kerjasama dalam Bidang Ekonomi kreatif yang disahkan pada 31 Agustus 2018. 


\section{DAFTAR PUSTAKA}

Abubakar Eby Hara, Pengantar Analisis Politik Luar Negeri: Dari Realisme sampai Konstruktivisme (Bandung: Nuansa, 2011).

Wendt ,Alexander E.1987. The Agent-Structure Problem in International Relations Theory. International Organization, Vol. 41, No. 3. (Summer, 1987), pp. 335-370.

Nota Kesepahaman tentang Kerjasama di Bidang Ekonomi Kreatif antara Pemerintah Republik Indonesia dan Pemerintah Australia.Treaty database.kemlu.go.id

Embassy Australia. Indonesia dan Australia: Mitra untuk Era Digital https://indonesia.embassy.gov.au/jaktindonesian/SM18_007.html 